\title{
Mechanical properties of thermally modified beech timber for structural purposes
}

\section{Journal Article}

Author(s):

Widmann, Robert; Fernandez-Cabo, José L.; Steiger, René

Publication date:

2012-11

Permanent link:

https://doi.org/10.3929/ethz-b-000057969

Rights / license:

In Copyright - Non-Commercial Use Permitted

Originally published in:

European Journal of Wood and Wood Products 70(6), https://doi.org/10.1007/s00107-012-0615-x 


\title{
Mechanical properties of thermally modified beech timber for structural purposes
}

\author{
Robert Widmann · José L. Fernandez-Cabo • \\ René Steiger
}

Received: 3 March 2011 / Published online: 22 June 2012

(C) Springer-Verlag 2012

\begin{abstract}
The use of thermally modified timber for structural purposes is of increasing interest. In order to guarantee sufficient reliability in terms of load bearing capacity and fitness for use the strength and stiffness properties of this modified wood have to be assessed. Industrially produced, thermally modified structural timber members made of beech (Fagus sylvatica L.) were subject of the tests presented in this paper. Bending, tension parallel and perpendicular to grain and compression parallel and perpendicular to grain properties were determined. The derived mechanical properties were benchmarked to the European EN 338 strength class system for structural timber. It turned out that the used strong thermal treatment of the raw material resulted in a significant reduction of most of the strength properties. However, stiffness properties were not affected. In particular the strength properties perpendicular to grain suffered a lot due to the thermal modification whereas compression strength parallel to grain was unchanged. The main drawbacks found along the experiments were a pronounced brittle behaviour of the specimens and big variations in strength. For the determination of strength values it is proposed not to use correlations as provided in European standards but to test and state these properties discretely. On the basis of these results a general use of strongly thermally modified beech as structural timber cannot be recommended. However, for
\end{abstract}

\section{R. Widmann $(\bowtie) \cdot$ R. Steiger}

Empa, Swiss Federal Laboratories for Materials Science and Technology, Structural Engineering Research Laboratory, Ueberlandstrasse 129, 8600 Duebendorf, Switzerland

e-mail: robert.widmann@empa.ch

\section{J. L. Fernandez-Cabo}

ETS of Architecture, Structural Department, Technical

University of Madrid, Avda. Juan de Herrera, 4,

28040 Madrid, Spain selected purposes, like e.g., for structural façade elements or for columns, the use of this material might be an option.

\section{Mechanische Eigenschaften von thermisch modifizier- tem Buchenholz für tragende Bauteile}

Zusammenfassung Die Verwendung von thermisch modifiziertem Holz erfreut sich wachsender Beliebtheit. Für eine Erweiterung der möglichen Anwendungen auf tragende Bauteile müssen deren Festigkeits- und Steifigkeitseigenschaften bekannt sein. Industriell thermisch behandeltes Buchenholz (Fagus sylvatica L.) in Bauteilabmessungen wurde Biege-, Zug- und Druckversuchen parallel und senkrecht zur Faser unterzogen. Die ermittelten Parameter wurden den Festigkeitsklassen nach EN 338 zugeordnet. Es zeigte sich, dass die verwendete intensive thermische Modifikation zu einer signifikanten Reduktion der Festigkeitseigenschaften führte, während die Steifigkeiten mehr oder weniger unverändert blieben. Besonders betroffen von der Reduktion der Werte waren die Festigkeiten senkrecht zur Faser des thermisch behandelten Holzes. Als großes Manko des Materials erwies sich während der Versuche das spröde Bruchverhalten sowie die große Streuung der Festigkeitswerte. Auf der Basis der Resultate kann das verwendete stark thermisch modifizierte Buchenholz nicht für eine generelle Verwendung in tragenden Bauteilen empfohlen werden. Für spezielle Anwendungen, beispielsweise Stützen oder Fassadenelemente, könnte der Einsatz dieses Materials jedoch eine Option sein.

\section{Introduction}

Thermally modified timber (TMT) has become a considerable alternative to tropical hardwoods or impregnated 
softwoods for several applications within the past decade. Its treatment dependant adjustable light to dark colour (Yixing et al. 1994; Johansson and Morén 2006; FinnishThermowood-Association 2003; Bekhta and Niemz 2005) and improved dimensional stability (Burmester 1975; Hillis 1984; Kollmann and Schneider 1963; Seborg et al. 1953) helped to introduce it into the flooring-, claddingand furniture market. As thermal treatment of wood also leads to higher durability compared to untreated wood (Kamdem et al. 2002; Hakkou et al. 2006), the use of TMT for products that are exposed to a humid environment like façade panels, decks and floorings for bathrooms became evident. The EC-funded FP6 project HOLIWOOD (Schöftner 2007) aimed at widening the field of application for TMT made of European hardwoods-here in particular beech (Fagus sylvatica L.) - to structural applications in an outdoor environment, e.g., for load bearing members of industrial buildings and noise barrier elements.

While the modulus of elasticity (MOE) of thermally modified soft- and hardwood remains unchanged or even slightly increases compared to untreated wood (Millett and Gerhards 1972), it is known that a downside of the thermal treatment is the resulting reduced strength compared to untreated wood (Rusche 1973a; Millett and Gerhards 1972). Some analyses showed that for a given thermal treatment hardwoods show even higher strength losses than softwoods (Hill 2006; Chang and Keith 1978).

Several studies fully or partly deal with the consequences of thermal treatment on the mechanical behaviour of wood. However, a vast majority of the correspondent tests have been done on small clear specimens. For a structural use of TMT of beech (TMTB) the strength and stiffness values have to be derived according to relevant standards, e.g. European standard EN 338 (CEN 2009) and/or they have to be determined by tests, e.g. following the procedures of EN 384 (CEN 2010a) and EN 408 (CEN 2010b). For most of these tests timber specimens in a structural size have to be used. According to EN 384 (CEN 2010a) three basic characteristic values, bending strength, mean modulus of elasticity MOE parallel to grain and density, need to be determined for assigning grades and species to EN 338 (CEN 2009) strength classes. For a typical timber, other properties may be derived from the basic values using correlations as given in this standard. However, preliminary tests indicated that for TMTB the relation between several strength/stiffness parameters could differ significantly from respective specifications given in EN 338 (CEN 2009). Therefore, the tests had to cover all parameters that are needed to assign TMTB to a respective strength class. The objective of the present study was to provide strength and stiffness data of TMTB for its possible use as a structural material.

\section{Materials and methods}

\subsection{Raw material}

The beech wood was taken from three different stands in Austria, namely from Upper Austria (TMTB 1), Wiener Wald (TMTB 2) and Ennstal/Yppstal. (TMTB 3). The wood was ordered appearance graded as "Custom Shop" (Pollmeier 2009).

Visual strength grading was carried out with the already heat treated specimens immediately before testing. All specimens met the requirements for strength class LS13 according to the German standard DIN 4074-5 (DIN 2008) which would permit an assignment of the samples to strength class D40 according to EN 1912 (CEN 2010c). The specimens were free of major defects like big knots and also did not show significant twist or bow deformations. However, cup deformations as a consequence of the thermal treatment existed in almost all the beams and boards but did not exceed the limit of $2 \%$. Slope of grain is generally difficult to determine on beech timber and thus was disregarded as grading criteria which is in line with the requirements according to DIN 4074-5 (DIN 2008). The effective quality of the untreated timber-in particular regarding the absence of significant knots-implies a much greater potential for these wood samples than strength class D40 which is in line with studies on the strength of glulam beams made of beech (Frese and Blass 2007).

\subsection{Thermal modification}

The specimens were thermally treated by Mitteramskogler GmbH in Gaflenz, Austria. This company uses the Thermoholz Austria (THA) thermal treatment process where the respective modification is executed under gas atmosphere. According to the desired end-use of the material, the heating temperature can vary between 170 and $230{ }^{\circ} \mathrm{C}$ (Mitteramskogler 2008) with treatment times between 2 and $16 \mathrm{~h}$ and total process times of 24-64 h (Mitteramskogler 2007). The tested wood was modified under relatively low temperature $\left(180-190{ }^{\circ} \mathrm{C}\right.$ ) and long treatment time (16 h). However, the detailed process data are confidential and thus cannot be published. The treatment is being regarded as an intensive modification and should offer a compromise between good dimensional stability and durability on the one hand and an assumed acceptable decrease in mechanical properties on the other hand.

\subsection{Specimens}

The nominal dimensions of the raw material were length $(l) \cdot$ width $(b) \cdot$ depth $(h)=3,000 \cdot 50 \cdot 150 \mathrm{~mm}^{3}$ for the beams and $l \cdot b \cdot h=3,000 \cdot 150 \cdot 35 \mathrm{~mm}^{3}$ for the 
boards. Influenced by the drying- and thermal treatment processes, actual widths and depths varied slightly. According to the manufacturer the thickness of the beams represented the maximum that can be realised if homogeneous thermal modification of the entire cross section is required.

There were $n=100$ square-cut TMTB beams and $n=40$ boards per sample available for testing. For sampling see Fig. 1.

In Table 1 the specimens are listed with their numbers and dimensions. The factor $k_{\mathrm{s}}$ in the Table indicates if a penalty on the strength values as a function of number of samples and sample size had to be taken into account according to EN 384 (CEN 2010a). For some tests the effective number of specimens differed slightly from what is indicated in Table 1 due to unreliable data or system errors that occurred while testing. The effective number of specimens per test is shown in the results section. A small sample of $n=14$ specimens of untreated beech timber obtained from the second stand (TMTB 2-Beech 2) was

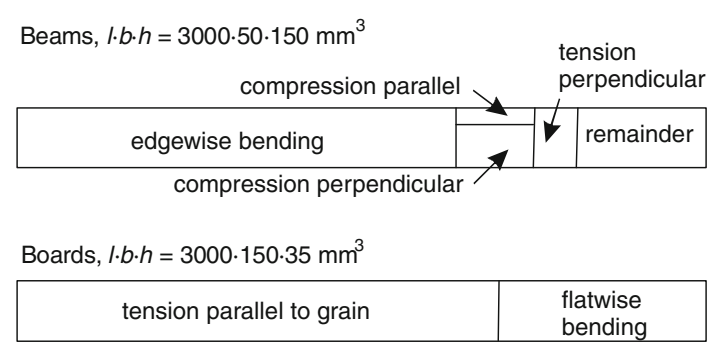

Fig. 1 Sampling of the specimens

Abb. 1 Entnahme der Probekörper used as a reference for the bending, tension and compression parameters of the raw material.

\subsection{Moisture content}

Apart from the bending specimens all other specimens were conditioned in standard climate $\left(20{ }^{\circ} \mathrm{C}, 65 \%\right.$ relative humidity) and the effective moisture content (MC) was determined by the oven-dry method according to EN 13183-1 (CEN 2002). The results of these tests are listed in Table 2.

\section{Experimental procedures}

With the exception of the tension perpendicular to grain tests all tests were executed according to the relevant European standards EN 408 (CEN 2010b) and EN 384 (CEN 2010a). For all strength tests short term ramp loading rates were chosen with the aim of reaching failure within $300 \pm 120 \mathrm{~s}$.

The density $\rho$ of the single specimens was determined immediately prior to testing from the mass of the entire bending specimens divided by their volume according to ISO 3131 (ISO 1975). Before the bending tests were executed, the dynamic MOE $E_{\text {dyn }}$ of the beams and boards was determined. The ultrasonic device "Sylvatest" was used to measure the longitudinal wave velocity $v$ within each specimen. Together with the density $\rho$ measured at the same time it was possible to determine $E_{\mathrm{dyn}}$ on the basis of the theory of longitudinal stress wave propagation: $E_{\mathrm{dyn}}=\rho \cdot v^{2}$.

Table 1 Specimens used for structural tests of TMTB

Tab. 1 Probekörper für die Belastungsversuche mit TMTB

\begin{tabular}{|c|c|c|c|c|c|c|c|c|}
\hline \multirow[t]{2}{*}{ Property } & \multirow[t]{2}{*}{ Symbol } & \multicolumn{3}{|c|}{ Samples $\times$ size } & \multicolumn{3}{|c|}{ Nominal specimen dimensions } & \multirow{2}{*}{$\begin{array}{l}\text { Specimens according } \\
\text { EN } 384 \text { and EN } 408\end{array}$} \\
\hline & & $n$ & $k_{\mathrm{s}}$ & Ref. $n$ & Length $l[\mathrm{~mm}]$ & Width $b[\mathrm{~mm}]$ & Depth $h[\mathrm{~mm}]$ & \\
\hline Density & $\rho$ & $3 \times 100$ & - & $1 \times 14$ & 2,150 & 50 & 135 & Yes \\
\hline Bending strength and MOE & $f_{\mathrm{m}}, E_{0}$ & $3 \times 100$ & 0.95 & $1 \times 14$ & 2,150 & 50 & 135 & Yes \\
\hline Bending strength and MOE & $f_{\mathrm{m}}, E_{0}$ & $3 \times 40$ & 0.89 & & 600 & 150 & 35 & Yes \\
\hline Tension strength ॥ & $f_{\mathrm{t}, 0}$ & $3 \times 40$ & 0.89 & & 2,220 & 150 & 35 & Yes \\
\hline Tension MOE ॥ & $E_{\mathrm{t}, 0}$ & $2 \times 20$ & - & & 2,220 & 150 & 35 & Yes \\
\hline Tension strength $\perp$ & $f_{\mathrm{t}, 90}$ & $3 \times 40$ & 1.0 & $1 \times 14$ & 50 & 60 & 50 & No \\
\hline Compression strength ॥ & $f_{\mathrm{c}, 0}$ & $3 \times 100$ & 0.95 & $1 \times 14$ & 180 & 30 & 30 & No \\
\hline Compression strength $\perp$ & $f_{\mathrm{c}, 90}$ & $3 \times 100$ & 1.0 & $1 \times 14$ & 70 & 45 & 90 & Yes \\
\hline
\end{tabular}

Factor $k_{\mathrm{s}}$ indicates if a penalty on the strength values as a function of numbers of samples and sample size had to be taken into account according to EN 384 (CEN 2010a). It is only applied for the calculation of characteristic values. "Ref." indicates the presence of a reference sample and its size. $\|=$ parallel to the grain, $\perp=$ perpendicular to the grain

Der Faktor $k_{\mathrm{s}}$ berücksichtigt die Anzahl der Stichproben und den Probenumfang gemäß EN 384 (CEN 2010a). Der Faktor wird nur für die Bestimmung der charakteristischen Werte angewendet. "Ref." zeigt die Verfügbarkeit einer Referenzstichprobe an, sowie deren Größe. $\|=$ parallel zur Faserrichtung, $\perp=$ senkrecht zur Faserrichtung. 
The bending tests were executed in a 4-point loading configuration with the tension edge selected at random (Fig. 2a). The bending MOE was determined on the basis of the measured total deflection as global bending MOE $E_{\mathrm{m}, \mathrm{g}}$ and on the basis of the relative beam deflection in between the two loading points as local MOE $E_{\mathrm{m}, 1}$. The 4-point loading set-up was also used for the bending tests of the boards (flatwise) with the relevant lengths adapted to the nominal board's depth of $35 \mathrm{~mm}$.

Table 2 Density and respective moisture content of the test samples as determined on the bending specimens

Tab. 2 Rohdichte und zugehörige Holzfeuchte der Probekörper, bestimmt an den Biegeprobekörpern

\begin{tabular}{llll}
\hline Series & Treatment & $\begin{array}{l}\text { Density } \\
\rho\left[\mathrm{kg} / \mathrm{m}^{3}\right]\end{array}$ & $\begin{array}{l}\text { Moisture content } \\
\text { MC [\%] }\end{array}$ \\
\hline TMTB 1 & Forte & $500-670$ & $4.6-6.5$ \\
TMTB 2 & Forte & $530-800$ & $5.2-6.2$ \\
TMTB 3 & Forte & $570-760$ & $4.6-6.3$ \\
Beech 2 & Untreated & $670-820$ & $11.9-13.7$ \\
\hline
\end{tabular}

The tension tests parallel to grain were executed in a tension testing device with full board cross sections (Fig. 2b). The boards were clamped on a length of $320 \mathrm{~mm}$ on either end and the clear distance between the grips was $1,580 \mathrm{~mm}$. On two out of the three TMTB samples the tension MOE $E_{\mathrm{t}, 0}$ was determined using a gauge length of $750 \mathrm{~mm}$. The relevant deformations were measured on both edges of the boards.

Tensile strength perpendicular to grain was not determined according to EN 408 but rather according to the EN 302-3 (CEN 2004) procedure for assessment of glue line strength. The specimens were cut such that a loading in radial direction resulted, as shown in Fig. 2c. The strength was calculated from the maximum force and the minimum cross section of $25 \cdot 50 \mathrm{~mm}^{2}$. Compression strength parallel and perpendicular to the grain was determined on prismatic specimens as indicated in EN 408 (CEN 2010b). For the tests perpendicular to the grain the compression strength was determined according the procedure given in EN 408 and shown in Fig. 2d.
Fig. 2 Test configurations for bending (a), tension parallel (b) and perpendicular to grain (c), as well as compression perpendicular (d) and parallel to grain (e). All dimensions are indicated in millimeters Abb. 2 Test-Konfigurationen für Biegung (a), Zug parallel (b) und senkrecht (c), zur Faserrichtung sowie für Druck parallel (d) und senkrecht (e) zur Faserrichtung. Alle Abmessungen in Millimeter

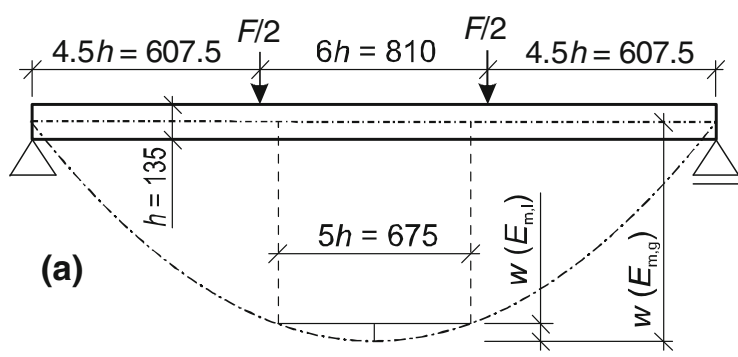

(b)
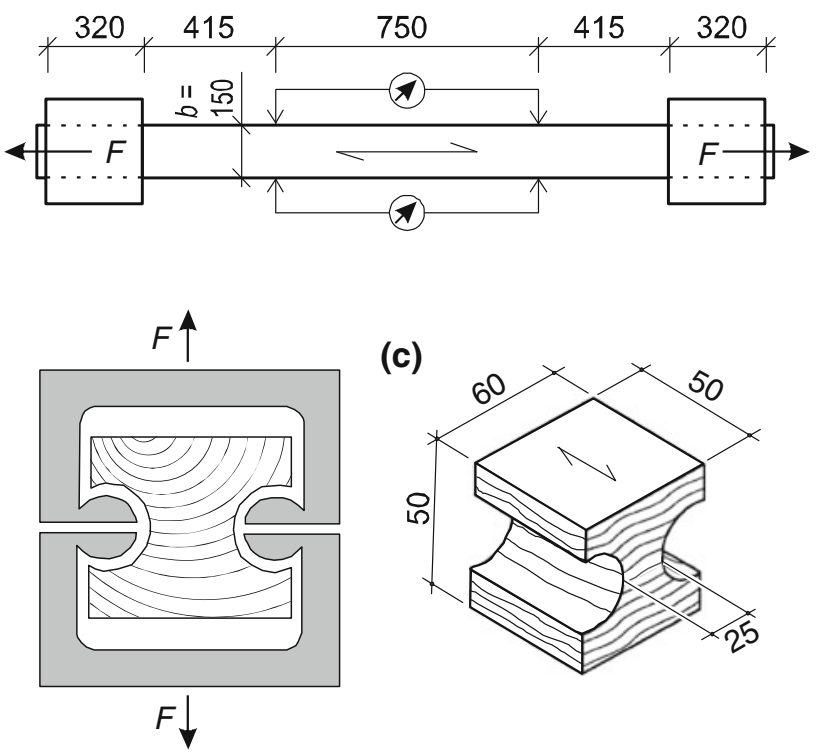

(c)

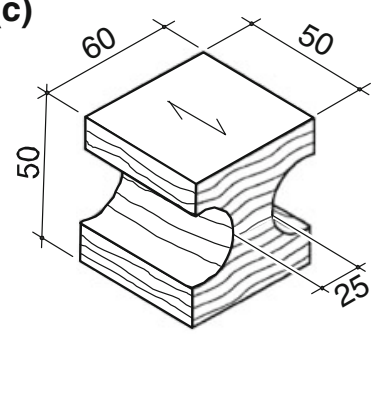

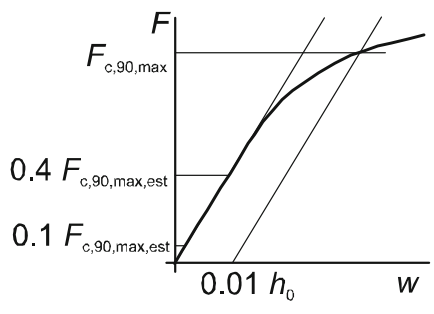

(d) $\quad x_{F \downarrow}^{b=45}$
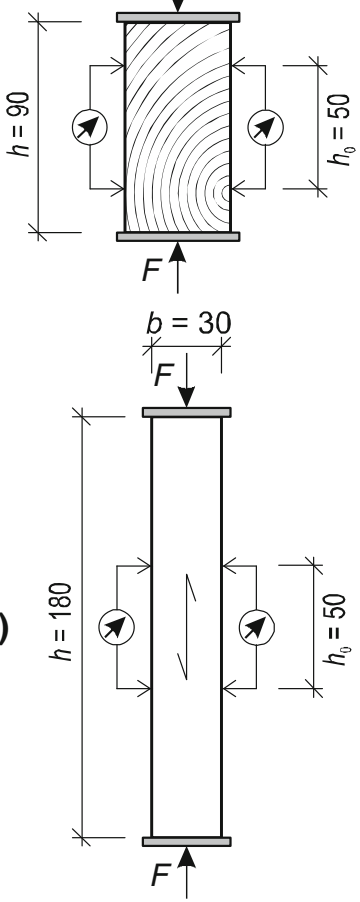
In Fig. 2e the set-up for tests regarding compression strength parallel to the grain is shown. These tests in general complied with EN 408. However, the tests were not executed with the full cross section, e.g., from the beams $b \cdot h=150 \cdot 50 \mathrm{~mm}^{2}$ but with cross sections of $b \cdot h=30 \cdot 30 \mathrm{~mm}^{2}$.

\section{Results and discussion}

\subsection{General}

All results are shown as boxplots which include minimum and maximum values as well as quartiles and mean values (X). If a 5-percentile was determined, it is also shown in the graph (o). The quartiles shown in the graphs were calculated using the method provided by (NIST 2010) and as it is used in MS-Excel. In contrary to that, the 5-percentile values shown in the graphs and taken as basis for the calculation of characteristic values according to EN 384 (CEN 2010a) were determined by ranking and interpolation between neighbour ranks if required. In addition the sample size $n$ and the coefficient of variation $\mathrm{CoV}$ is stated.

The level of confidence for statistical analysis was set to $95 \%$ in general.

\subsection{Density $\rho$}

The boxplots shown in Fig. 3 represent the density of the beams that were tested in bending. The mean values were in the range of $600-660 \mathrm{~kg} / \mathrm{m}^{3}$ for the TMTB samples and $730 \mathrm{~kg} / \mathrm{m}^{3}$ for the control sample. The decrease in density due to the "forte" heat treatment can be estimated on the basis of direct comparison of the samples TMTB 2 and Beech 2 and amounted to about $10 \%$ at the mean level. This is in the range of published values, with on the one hand a comparable density reduction after strong heat treatment in vacuum according to Rusche (1973b) and on the other hand a range of $700-790 \mathrm{~kg} / \mathrm{m}^{3}$ for untreated beech (Sell 1997).

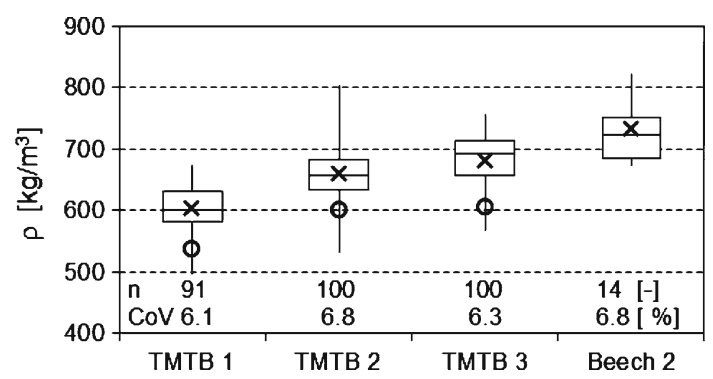

Fig. 3 Density of TMTB samples 1-3 and reference sample Beech 2 Abb. 3 Rohdichte der TMTB Stichproben 1-3 und der Referenzstichprobe Buche 2
The characteristic value of density was calculated to be $\rho_{\mathrm{k}}=580 \mathrm{~kg} / \mathrm{m}^{3}$. This would allow assigning the tested TMTB batches to strength class D40 according to EN 338 (CEN 2009), whereas the obtained mean value of density of $650 \mathrm{~kg} / \mathrm{m}^{3}$ only matches strength class D35.

\subsection{Bending strength $f_{\mathrm{m}}$ of beans}

When tested in bending the TMTB square-cut beams exhibited pronounced brittle failures. Those ten specimens per sample with the lowest bending strength were analysed visually in order to obtain information about possible reasons for the brittle failures and the low strength values. On several specimens general or local significantly increased angles of grain in the failure area could be observed; whereas for some other beams no visual indicators for the low strength could be found.

The mean bending strength of TMTB with the mentioned heat treatment reaches about $65 \%$ of the mean bending strength of untreated beech (Fig. 4a). With regard to structural applications 5-percentile (characteristic) values are decisive and at this level the drop in bending strength exceeds $50 \%$. This goes in line with higher strength variations within the treated samples compared to the untreated control sample (CoV in Fig. 4a).

When estimating the characteristic bending strength of each sample by applying the relevant factors $k_{\mathrm{h}}, k_{1}$ and $k_{\mathrm{s}}$ (Table 1) according to EN 384 (CEN 2010a) the overall characteristic bending strength results in $f_{\mathrm{m}, \mathrm{k}}=30.8 \mathrm{MPa}$. This value matches EN 338 (CEN 2009) strength class D30. It has to be noted, that within the sample TMTB 1 the minimum observed bending strength amounted to only 16.2 MPa. This low value questions the usability of this material for structural purposes.

\subsection{Global and local bending $\operatorname{MOE} E_{\mathrm{m}, \mathrm{g}}$ and $E_{\mathrm{m}, 1}$}

In Fig. $4 \mathrm{~b}$ the results of the local bending MOE measurements are compared and in Table 3 the discrete values for $E_{0}$ are given based on local and global MOE. There is no significant difference between MOE of treated and untreated beech (Fig. 4b). In relation to published data of untreated beech (Sell 1997; Wood handbook 1999) the mean values are located in the upper region of the bandwidth.

It is known from literature that global MOE $E_{\mathrm{m}, \mathrm{g}}$ and local MOE $E_{\mathrm{m}, 1}$ correlate well for untreated timber and this could be verified also for the data of this study. The correlation $E_{\mathrm{m}, 1}=1.3 E_{\mathrm{m}, \mathrm{g}}-2.69[\mathrm{GPa}]$ given in $\mathrm{EN} 384$ (CEN 2010a) fits the data quite well. A linear regression without offset: $E_{\mathrm{m}, 1}=1.15 E_{\mathrm{m}, \mathrm{g}}$ fitted the data as well $\left(\mathrm{R}^{2}=0.90\right)$ and is in the very same range as what was found by Ravenshorst and van de Kuilen (2009) for several 
Fig. 4 Bending properties of TMTB samples $1-3$ and reference sample Beech 2: a Bending strength $f_{\mathrm{m}}$. and b local bending MOE $E_{\mathrm{m}, 1}$ Abb. 4 Biegeeigenschaften der TMTB Stichproben 1-3 und der Referenzstichprobe Buche 2: a Biegefestigkeit $f_{\mathrm{m}}$ und b lokaler Biege-E-Modul $E_{\mathrm{m}, 1}$

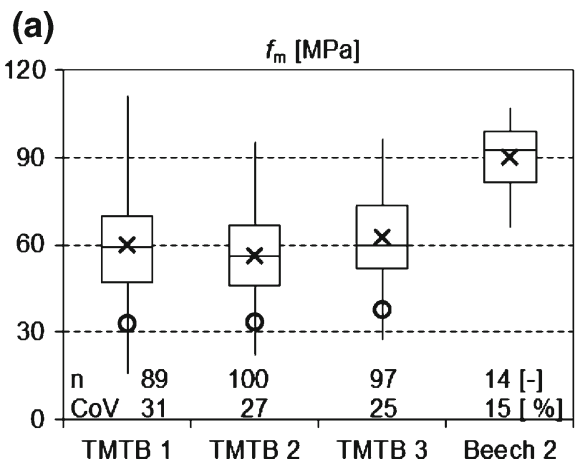

Table 3 Mean values and 5-percentile values of the bending MOE $E_{0}$ of the TMTB samples on the basis of the measured $E_{\mathrm{m}, \mathrm{g}}$ and $E_{\mathrm{m}, 1}$ according to EN 384 (CEN 2010a) and compared to strength class D50 according to EN 338 (CEN 2009)

Tab. 3 Mittelwerte und 5\%-Fraktilwerte des Biege-E-Moduls $E_{0}$ der TMTB-Probekörper auf Basis der gemäß EN 384 (CEN 2010a) gemessenen Werte $E_{m, g}$ und $E_{m, 1}$ im Vergleich mit Werten der Festigkeitsklasse D50 nach EN 338 (CEN 2009)

\begin{tabular}{lccc}
\hline$E_{0}=$ & $E_{\mathrm{m}, 1}$ & $1.3 E_{\mathrm{m}, \mathrm{g}}-2.69$ & $\mathrm{D} 50$ \\
\hline$E_{0, \text { mean }}[\mathrm{GPa}]$ & 16.6 & 16.0 & 14.0 \\
$E_{0,05}[\mathrm{GPa}]$ & 12.8 & 12.0 & 11.8 \\
$E_{0,05} / E_{0, \text { mean }}$ & 0.77 & 0.75 & 0.84 \\
\hline
\end{tabular}

unmodified soft- and hardwoods. The MOE values permit to classify the TMTB as strength class D50.

\subsection{Compression strength parallel to the grain $f_{\mathrm{c}, 0}$}

In Fig. 5 the results of the compression tests parallel to the grain are shown. It can be seen, that the compression strength parallel to the grain of the treated and untreated samples do not differ that markedly as they do in case of other strength properties, like e.g., bending strength $f_{\mathrm{m}}$.

According to EN 384 (CEN 2010a) the characteristic compression strength parallel to grain $f_{\mathrm{c}, 0, \mathrm{k}}$ can be derived from the characteristic value of bending strength $f_{\mathrm{m}, \mathrm{k}}$. With respect to the observed characteristic value of bending

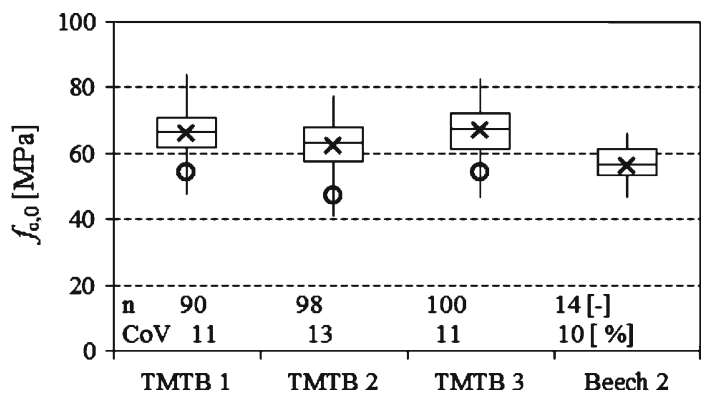

Fig. 5 Compression strength parallel to grain $f_{\mathrm{c}, 0}$ of TMTB sample 1-3 and reference sample Beech 2

Abb. 5 Druckfestigkeit parallel zur Faserrichtung $f_{c, 0}$ der TMTB Stichproben 1-3 und der Referenzstichprobe Buche

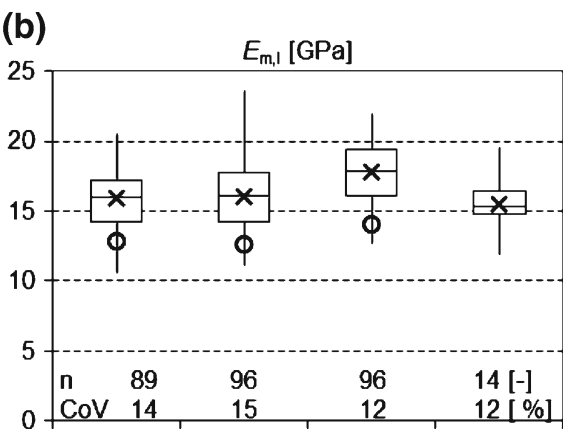

тмтв 1 тмтв 2 тмтВ 3 Beech 2 strength $f_{\mathrm{m}, \mathrm{k}}=30.8 \mathrm{MPa}$ the corresponding characteristic value of compression strength parallel to grain should be:

$f_{\mathrm{c}, 0, \mathrm{k}}=5 \cdot\left(f_{\mathrm{m}, \mathrm{k}}\right)^{0.45}=5 \cdot 30.8^{0.45}=23.4 \mathrm{MPa}$

The observed compression strength values parallel to grain of TMTB exceeded this by far (Fig. 5). On the basis of the determined $f_{\mathrm{c}, 0, \mathrm{k}}=48.7 \mathrm{MPa}$ TMTB would fit into the highest strength class D70 according to EN 338 (CEN 2009). The mean value of compression strength parallel to the grain reached $f_{\mathrm{c}, 0 \text {,mean }}=65.2 \mathrm{MPa}$ and hence was located in the upper range of published values for untreated small clear beech wood specimens (Sell 1997). For compression strength parallel to grain it can be stated that this strength obviously is not negatively affected by the thermal modification.

\subsection{Compression strength perpendicular to the grain $f_{\mathrm{c}, 90}$}

The performance of TMTB regarding compression perpendicular to the grain differed strongly from its good performance in case of compression parallel to grain. In Fig. $6 \mathrm{a}$ it can be seen that at the mean level the compression strength perpendicular to grain of the modified samples drops below about $80 \%$ of the strength of the untreated sample. The drop in strength at the $5 \%$ level can be estimated as being even more pronounced.

The calculated characteristic value of compression strength perpendicular to the grain $f_{\mathrm{c}, 90, \mathrm{k}}=6.16 \mathrm{MPa}$ implies that TMTB cannot be allocated to even the lowest hardwood strength class D18 (EN 338: $f_{\mathrm{c}, 90, \mathrm{k}}=7.5 \mathrm{MPa}$ ), but on the other hand exceeds the compression strength of the highest softwood strength class C50 (EN 338: $f_{\mathrm{c}, 90, \mathrm{k}}=$ $3.2 \mathrm{MPa})$ by far.

In general the linear regression of the correlated average compression strength perpendicular to grain and density corresponds well with the standard (EN 384: $f_{\mathrm{c}, 90}=$ $0.015 \rho$ ). However, this represents the mean level and at the 5-percentile level the characteristic compression strength perpendicular to grain $f_{\mathrm{c}, 90, \mathrm{k}}$ of TMTB would be overestimated because: 
Fig. 6 Compression properties perpendicular to grain of TMTB samples $1-3$ and reference sample Beech 2: a Compression strength $f_{\mathrm{c}, 90}$. and $\mathbf{b}$ compression MOE $E_{90}$

Abb. 6 Druckeigenschaften senkrecht zur Faserrichtung der TMTB Stichproben 1-3 und der Referenzstichprobe Buche 2: a Druckfestigkeit $f_{\mathrm{c}, 90}$. und b Druck-E-Modul $E_{90}$

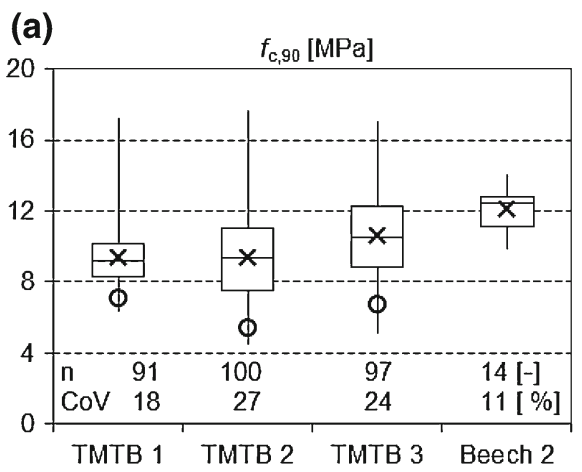

$f_{\mathrm{c}, 90, \mathrm{k}} / \rho_{\mathrm{k}}=6.16 / 580=0.010<0.015$.

Hence, the correlation given in EN 384 cannot be used for TMTB and characteristic values of compression strength perpendicular to grain of TMTB have to be stated discretely.

4.7 MOE perpendicular to the grain $E_{90}$ determined in compression

The MOE in compression perpendicular to the grain of the TMTB was found to be significantly higher than the one of the untreated sample (Fig. 6b). The mean value of the MOE came to $0.934 \mathrm{GPa}$ which fits strength class D50 according to EN 338 (CEN 2009). The effective ratio $E_{0, \text { mean }} / E_{90, \text { mean }}=16.6 / 0.934=17.8$ is higher than the ratio given in EN 384 with $E_{0, \text { mean }} / E_{90 \text {,mean }}=15$. This means that the average MOE perpendicular to the grain of TMTB would be overestimated by around $18 \%$ if it was determined on the basis of the MOE parallel to the grain following the procedure in EN 338 (CEN 2009) and hence this correlation cannot be used for TMTB.
4.8 Tension strength parallel to the grain $f_{\mathrm{t}, 0}$ and bending strength $f_{\mathrm{m}}$ of boards

More than $60 \%$ of all failures occurred partly or completely within the clamping jaws. This indicates that TMTB might be sensitive to multi-axial stresses. The tension strength parallel to the grain varied strongly as can be seen in Fig. 7a. On the basis of the 5-percentiles and the procedures given in EN 384 (CEN 2010a) a characteristic value of tension strength parallel to the grain $f_{\mathrm{t}, 0, \mathrm{k}}=$ 14.4 MPa was determined, which is in the range of strength class D24. The characteristic bending strength of the boards was adjusted to a reference depth of $150 \mathrm{~mm}$ (EN 384) and resulted in $f_{\mathrm{m}, \mathrm{k}}=29.8 \mathrm{MPa}$.

In EN 384 (CEN 2010a) a ratio of characteristic values of tension and bending strength of $f_{\mathrm{t}, 0, \mathrm{k}} / f_{\mathrm{m}, \mathrm{k}}=0.6$ is assumed. With the data of this study a ratio of only 0.48 could be calculated. Therefore, it is not suggested to use the correlation rate of 0.6 for the determination of the characteristic tension strength on the basis of a known characteristic value of bending strength of TMTB.

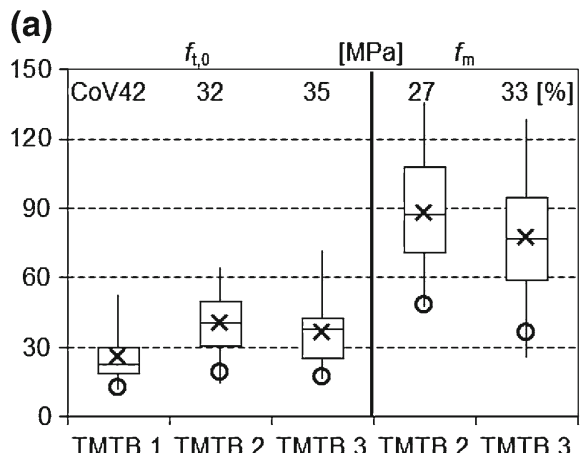

(b)

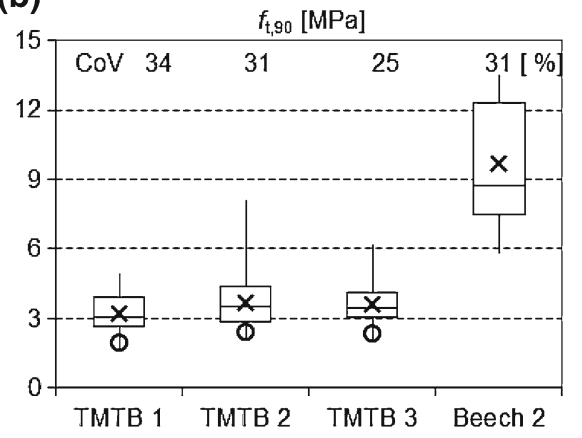

Fig. 7 a Tension strength parallel to grain $f_{\mathrm{t}, 0}$ and bending strength $f_{\mathrm{m}}$ determined on $n=40$ boards per sample. For these tests no untreated reference sample was available. b Tension strength perpendicular to grain $f_{\mathrm{t}, 90}$ determined on square-cut timber of TMTB samples 1-3 and reference sample Beech 2

Abb. 7 a Zugfestigkeit parallel zur Faserrichtung $f_{\mathrm{t}, 0}$ und Biegefestigkeit $f_{\mathrm{m}}$ von $n=40$ Brettern. Für diese Versuche stand keine Referenzstichprobe zur Verfügung. b Zugfestigkeit senkrecht zur Faserrichtung $f_{\mathrm{t}, 90}$ der TMTB Stichproben 1-3 und der Referenzstichprobe Buche 2 


\subsection{Tension strength perpendicular to the grain $f_{\mathrm{t}, 90}$}

The tension strength perpendicular to grain $f_{\mathrm{t}, 90}$ amounted to an average of $f_{\mathrm{t}, 90 \text {,mean }}=3.48 \mathrm{MPa}$ and a 5-percentile of $f_{\mathrm{t}, 90,05}=2.15 \mathrm{MPa}$, respectively. A characteristic value was not determined as the tests were not executed according to EN 408 (CEN 2010b). However, a significant drop in strength due to the thermal treatment could be observed (Fig. 7b), and the tension strength $f_{\mathrm{t}, 90}$ of the sample TMTB 2 at the mean level reached only $38 \%$ of the untreated sample Beech 2. This represents by far the strongest decrease of all strength values tested within this study. In literature strength reductions due to thermal modifications in a similar high range are reported for impact bending strength of small clear specimens (Boonstra et al. 2007; Schneider 1971) as well as on timber structural members (Leijten 2004). In a study by MajanoMajano et al. (2010) the authors mention a reduction in fracture toughness of similar TMTB compared to untreated beech between 63 and $84 \%$ depending on the load direction (radial/tangential). This confirms the findings of this study, that the strength properties perpendicular to grain are reduced to a high degree. This reduction in tension strength perpendicular to grain might be the main reason for the partly shown articulated loss in other strength properties.

In particular for beech, where the angle of grain is difficult to determine and therefore is no grading criterion in the relevant standard DIN 4074-5 (DIN 2008), this appears to be obvious. From these tests it can be concluded that this visual grading parameter should be compulsory for TMTB and strict limits for the angle of grain should be introduced.

In addition it is clear that e.g. in the proximity of joints with metal fasteners stresses perpendicular to grain are present and it can be expected that the poor resistance of TMTB to these stresses will have a negative effect on the performance of such joints. Therefore, the poor strength in tension perpendicular to the grain is eventually being looked upon as the main drawback for the intended use of TMTB as a structural material.

\subsection{Overview of the strength and stiffness properties of TMTB}

In Table 4 an overview of the performance of the intensively modified TMTB is given. It can be seen, that some properties would allow assigning this TMTB to a high strength class according to EN 338 (CEN 2009). This is in particular true for the stiffness properties and the compression strength parallel to grain. However, the other strength parameters only permit an assignment to low strength classes. The shown range of strength classes suggests to state discrete values for each single property instead of assigning TMTB to one strength class according to the procedures in EN 384. If TMTB would succeed to enter the market of structural timber on a wider field it should be discussed to introduce specific strength classes for this kind of material.

\section{Conclusion}

Three samples of TMTB and one untreated control sample were subjected to standard tests in order to investigate their structural behaviour and to assign this type of modified timber to a strength class according to EN 338. From the tests presented in this study it can be concluded that:

- The MOE values parallel to the grain of TMTB are similar to or slightly exceed those of untreated beech timber and thus could lead to a classification of TMTB into high strength classes of e.g., D50.

Table 4 Overview of the derived characteristic- and/or mean values of density, strength and stiffness properties of TMTB Tab. 4 Übersicht der charakteristischen und/oder Mittelwerte der Rohdichte, Festigkeiten und Steifigkeiten von TMTB

\begin{tabular}{|c|c|c|c|c|c|c|}
\hline \multirow[t]{2}{*}{ Property } & \multicolumn{2}{|l|}{ Symbol } & \multirow[t]{2}{*}{ Unit } & \multirow[t]{2}{*}{ Value } & \multirow{2}{*}{$\begin{array}{l}\text { EN } 338 \\
\text { Strength class }\end{array}$} & \multirow{2}{*}{$\begin{array}{l}\text { Tests } \\
\text { acc. EN } 408\end{array}$} \\
\hline & EN 338 & EN 408 & & & & \\
\hline \multirow[t]{2}{*}{ Density } & $\rho_{\mathrm{k}}$ & & $\mathrm{kg} / \mathrm{m}^{3}$ & 580 & $\mathrm{D} 40$ & (Yes) \\
\hline & $\rho_{\text {mean }}$ & & $\mathrm{kg} / \mathrm{m}^{3}$ & 650 & D35 & (Yes) \\
\hline Bending strength & $f_{\mathrm{m}, \mathrm{k}}$ & & MPa & 30.8 & D30 & Yes \\
\hline Tension strength ॥ & $f_{\mathrm{t}, 0, \mathrm{k}}$ & & $\mathrm{MPa}$ & 14.4 & D24 & Yes \\
\hline Tension strength $\perp$ & $f_{\mathrm{t}, 90, \mathrm{k}}$ & & MPa & - & - & No \\
\hline Compression strength ॥ & $f_{\mathrm{c}, 0, \mathrm{k}}$ & & MPa & 48.7 & D70 & No \\
\hline Compression strength $\perp$ & $f_{\mathrm{c}, 90, \mathrm{k}}$ & & MPa & 6.16 & (C50) & Yes \\
\hline \multirow[t]{2}{*}{ MOE in bending } & $E_{0, \text { mean }}$ & $E_{\mathrm{m}, 1, \text { mean }}$ & $\mathrm{GPa}$ & 16.6 & D50 & Yes \\
\hline & $E_{0,05}$ & $E_{\mathrm{m}, 1,05}$ & GPa & 12.8 & D50 & Yes \\
\hline MOE in tension $\|$ & $\left(E_{0, \text { mean }}\right)$ & $E_{\mathrm{t}, 0, \text { mean }}$ & GPa & 16.7 & D60 & Yes \\
\hline MOE in compression $\perp$ & $E_{90, \text { mean }}$ & $E_{\mathrm{c}, 90, \text { mean }}$ & $\mathrm{GPa}$ & 0.93 & D50 & Yes \\
\hline
\end{tabular}


- With the exception of compression parallel to grain the strength values of TMTB are lower than those of untreated beech timber and thus would result in assigning TMTB to lower strength classes, e.g. D30 and lower.

- Most correlation factors to determine unknown strength and stiffness properties from basic characteristic values of bending strength, density and MOE, as given in EN 384 (CEN 2010a) for solid wood, cannot be used for TMTB.

- It is suggested not to assign TMTB to existing EN 338 strength classes but to state discrete properties which have to be determined by relevant tests for its structural use.

- The brittle behaviour of the material and the big variation of the test values is the main problem regarding its strength properties. Poor strength in tension perpendicular to the grain and great sensitivity to stress concentrations are likely to significantly limit the structural use of TMTB.

- The big variations in test results implies that a strict quality management for the thermal modification process has to be installed in order to obtain a reliable and even quality of the structural TMTB products.

Overall it looks like the application of TMTB that underwent strong thermal modification (like the one used for this study) as a structural material in an important quantity will be difficult to realize. Good stiffness properties (that are often decisive for the design of a timber structure) face relatively low strength properties which in addition vary strongly. The brittleness of the material and its susceptibility to stress concentrations and multidimensional stresses are other important downsides that will come into play when it gets to e.g., the load-bearing behaviour of joints. Therefore, it is suggested to restrict the use of intensively treated TMTB to structural members with comparably low levels of load and/or to selected purposes where it can play out its strength, e.g., for short columns or for structural boards in cladding sandwich elements.

Acknowledgments The presented work was financially supported by the European Commission under contract No. NMP2-CT-2005011799 (HOLIWOOD project). The authors would like to thank Mitteramskogler GmbH for the supply of the material and the technical staff of Empa for the support in test preparation and execution.

\section{References}

Bekhta P, Niemz P (2005) Effect of high temperature on the change in color, dimensional stability and mechanical properties of spruce wood. Holzforschung 57(5):539-546

Boonstra MJ, Van Acker J, Tjeerdsma BF, Kegel EV (2007) Strength properties of thermally modified softwoods and its relation to polymeric structural wood constituents. Ann For Sci 64:679-690
Burmester A (1975) Dimensional stabilization of wood. Holz RohWerkst 33(9):333-335

Chang CI, Keith CT (1978) Properties of heat-darkened wood: II. Mechanical properties and gluability. Report, Eastern Forest Products Laboratory, Ottawa, Canada

CEN ECfS (2002) EN 13183-1: Moisture content of a piece of sawn timber-part 1: Determination by oven dry method

CEN ECfS (2004) EN 302-3: Adhesives for load-bearing timber structures - test methods-part 3: determination of the effect of acid damage to wood fibres by temperature and humidity cycling on the transverse tensile strength

CEN ECfS (2009) EN 338: Structural timber-strength classes

CEN ECfS (2010a) EN 384: Structural timber-determination of characteristic values of mechanical properties and density

CEN ECfS (2010b) EN 408: Timber structures—structural timber and glued laminated timber-determination of some physical and mechanical properties

CEN ECfS (2010c) EN 1912 + A4: Structural timber-strength classes-assignment of visual grades and species

Finnish-Thermowood-Association (2003) Thermowood handbook. Finnish Thermowood Association, Helsinki

Frese M, Blass HJ (2007) Characteristic bending strength of beech glulam. Mater Struct 40(1):3-13

DIN GIfS (2008) DIN 4074-5 Strength grading of wood-part 5: Sawn hard wood

Hakkou M, Pétrissans M, Gérardin P, Zoulalian A (2006) Investigations of the reasons for fungal durability of heat-treated beech wood. Polym Degrad Stabil 91(2):393-397

Hill CAS (2006) Wood modification: chemical, thermal and other processes renewable resources. Wiley, Southern Gate

Hillis WE (1984) High-temperature and chemical effects on wood stability. 1. General considerations. Wood Sci Technol 18(4):281293

ISO IOfS (1975) ISO 3131: Wood; determination of density for physical and mechanical tests

Johansson D, Morén T (2006) The potential of colour measurement for strength prediction of thermally treated wood. Holz RohWerkst 64(2):104-110

Kamdem DP, Pizzi A, Jermannaud A (2002) Durability of heattreated wood. Holz Roh- Werkst 60(1):1-6

Kollmann F, Schneider A (1963) On the sorption behaviour of heat stabilized wood. Holz Roh- Werkst 21(3):77-85

Leijten AJM (2004) Heat treated wood and the influence on the impact bending strength. Heron 49(4):349

Majano-Majano A, Hughes M, Fernandez-Cabo JL (2010) The fracture toughness and properties of thermally modified beech and ash at different moisture contents. Wood Sci Technol 46(1):5-21

Millett MA, Gerhards GC (1972) Accelerated aging: residual weight and flexural properties of wood heated in air at $115^{\circ} \mathrm{C}$ to $175{ }^{\circ} \mathrm{C}$. Wood Sci 4(4):193-201

Mitteramskogler (2007) Esche, Buche und Eiche mit Hitze veredelt Mehr Wertschöpfung aus heimischen Wäldern

Mitteramskogler (2008) Mirako-thermowood

NIST: National Institute of Standards and Technology (2010) Percentile. In: Engineering statistics handbook

Pollmeier (2009) Pollmeier grading beech. Creuzburg, Germany

Ravenshorst GJP, van de Kuilen JWG (2009) Relationship between local, global and dynamic modulus of elasticity for soft- and hardwoods. In: CIB-W18, meeting 42, paper 42-10-1, Duebendorf, Switzerland

Rusche H (1973a) Thermal-degradation of wood at temperatures up to $200{ }^{\circ} \mathrm{C}$. 1. Strength properties of dried wood after heattreatment. Holz Roh- Werkst 31(7):273-281

Rusche H (1973b) Thermal degradation of wood at temperatures up to $200{ }^{\circ} \mathrm{C}$. 2. Reaction-kinetics of loss of mass during heattreatment of wood. Holz Roh- Werkst 31(8):307-312 
Schneider A (1971) Investigations on the influence of heat treatments within a range of temperature from $100{ }^{\circ} \mathrm{C}$ to $200{ }^{\circ} \mathrm{C}$ on the modulus of elaticity, maximum crushing strength and impact work of pine sapwood and beechwood. Holz Roh- Werkst 29(11):431-440

Schöftner R (2007) Holiwood-international research and development for innovative products made out of thermal modified timber. Paper presented at the 3rd European Conference on Wood Modification, Cardiff, UK
Seborg RM, Tarkow H, Stamm AJ (1953) Effect of heat upon the dimensional stabilisation of wood. For Prod J 3(9):59-67

Sell J (1997) Properties and characteristic values of wood species (in German). LIGNUM, Zürich

Wood handbook (1999). Forest Products Laboratory General Technical Report FPL-GTR-113

Yixing L, Jian L, Jinman W, Jinsong Y, Yanhua M (1994) The effect of heat treatment on different species wood colour. J For Res $5(4): 73-78$ 